\title{
GRAIN YIELD AND KERNEL CRUDE PROTEIN CONTENT INCREASES OF MAIZE HYBRIDS WITH LATE NITROGEN SIDE-DRESSING
}

\author{
Paulo Regis Ferreira da Silva ${ }^{1}$; Mércio Luiz Strieder ${ }^{1}$; Rúbia Patrícia da Silva Coser ${ }^{1}$; Lisandro \\ Rambo $^{1}$; Luís Sangoi ${ }^{*}$; Gilber Argenta ${ }^{3}$; Everton Leonardo Forsthofer ${ }^{3}$; Adriano Alves da Silva ${ }^{1}$ \\ ${ }^{1}$ UFRGS - Depto. de Plantas de Lavoura, C.P. 776 - 91501-970 - Porto Alegre, RS - Brasil. \\ ${ }^{2}$ UDESC - Depto. de Fitotecnia, C.P. 281 - 88520-000 - Lages, SC - Brasil. \\ ${ }^{3}$ Syngenta Seeds - Desenvolvimento de Produtos - Rod. BR 452, km 142 - 38400-974 - Uberlândia, MG - Brasil. \\ *Corresponding author<a2ls@cav.udesc.br>
}

\begin{abstract}
Physiological changes incorporated into current maize hybrids suggest the occurrence of modifications in the nitrogen uptake dynamics, improving plant ability to uptake $\mathrm{N}$ during grain filling. This may justify late $\mathrm{N}$ side-dressing whenever environmental constraints prevent adequate nitrogen supply during crops vegetative development. This study evaluates effects of nitrogen fertilization at booting and silking on grain yield and kernel crude protein contents of commercial maize hybrids. Two experiments were set up in Eldorado do Sul, RS, during the 2001/2002 and 2002/2003 growing seasons. In 2001/2002, treatments were composed of two hybrids (Agroceres 303 and Pioneer 32R21), three nitrogen rates applied during maize vegetative development $\left(30,80\right.$ and $\left.130 \mathrm{~kg} \mathrm{ha}^{-1}\right)$ and three nitrogen rates applied at silking $(0,50$ and $100 \mathrm{~kg}$ ha $^{-1}$ ). In 2002/2003, four hybrids (Agroceres 303, Pioneer 32R21, Dekalb 215 and Syngenta Penta) and four nitrogen rates side-dressed at booting $\left(0,50,100\right.$ and $\left.150 \mathrm{~kg} \cdot \mathrm{ha}^{-1}\right)$ were assessed. There were significant increments in grain yield and kernel crude protein content with nitrogen fertilization at booting and silking. Grain yield response to late $\mathrm{N}$ side-dressing differed among cultivars. The impact of nitrogen fertilization at silking was higher at the smallest rate of $\mathrm{N}$ during the plant vegetative development. Enhancements in grain yield with late $\mathrm{N}$ side-dressing resulted from increases in grain weight. Modern hybrids can uptake nitrogen during silking, contradicting the hypothesis that late $\mathrm{N}$ side-dressing is not efficient to improve maize grain yield.
\end{abstract}

Key words: Zea mays, nitrogen, fertilization timing, productivity

\section{RENDIMENTO E TEOR DE PROTEÍNA BRUTA NOS GRÃOS DE HÍBRIDOS DE MILHO COM ADUBAÇÃO NITROGENADA DE COBERTURA TARDIA}

RESUMO: Alterações morfo-fisiológicas introduzidas nos híbridos modernos de milho sugerem mudanças na dinâmica de absorção do nitrogênio, aumentando a habilidade da planta de absorvê-lo durante o enchimento de grãos. Isto pode justificar a utilização de coberturas nitrogenadas tardias sempre que restrições climáticas impedirem o suprimento adequado de nitrogênio durante o desenvolvimento vegetativo da cultura. Este estudo foi conduzido objetivando avaliar os efeitos da fertilização nitrogenada no emborrachamento e espigamento no rendimento e teor de proteína nos grãos de híbridos de milho. Dois experimentos foram instalados em Eldorado do Sul, RS, nos anos agrícolas de 2001/2002 e 2002/2003. Em 2001/2002, os tratamentos foram compostos por dois híbridos (Agroceres 303 e Pioneer 32R21), três doses de $\mathrm{N}$ aplicadas durante o desenvolvimento vegetativo $\left(30,80\right.$ e $\left.130 \mathrm{~kg} \mathrm{ha}^{-1}\right)$ e três doses de $\mathrm{N}$ aplicadas no espigamento (0, 50 e $100 \mathrm{~kg} \mathrm{ha}^{-1}$ ). Em 2002/2003, quatro híbridos (Agroceres 303, Pioneer 32R21, Dekalb 215 e Syngenta Penta) e quatro doses de N aplicadas no espigamento (0, 50, 100 e $\left.150 \mathrm{~kg} \mathrm{ha}^{-1}\right)$ foram testadas. A fertilização nitrogenada no emborrachamento e espigamento promoveu incrementos significativos no rendimento e teor de proteína bruta dos grãos. A resposta do rendimento de grãos à cobertura nitrogenada tardia diferiu entre as cultivares. O impacto da fertilização nitrogenada no espigamento foi maior quando se aplicou baixas doses de $\mathrm{N}$ na fase de desenvolvimento vegetativo. Os aumentos no rendimento de grãos obtidos com coberturas tardias deveram-se principalmente ao maior peso de grãos. Os híbridos contemporâneos são capazes de absorver $\mathrm{N}$ depois do espigamento, contradizendo a hipótese de que coberturas nitrogenadas tardias não são eficientes para aumentar o rendimento de grãos do milho.

Palavras-chave: Zea mays, nitrogênio, época de aplicação, produtividade 


\section{INTRODUCTION}

Breeding plants that uptake and use $\mathrm{N}$ more efficiently, and developing management practices that synchronize $\mathrm{N}$ fertilization and stages of maize with higher $\mathrm{N}$ demand are important strategies to increase efficiency of nitrogen use (Raun \& Johnson, 1999). The best period for $\mathrm{N}$ application depends on the degree of $\mathrm{N}$ deficiency, linked to the balance between quantity of $\mathrm{N}$ supplied by the soil and maize internal demand (Binder et al., 2000).

Recommendations for nitrogen fertilization rates in southern Brazil range from 10 to $30 \mathrm{~kg} \mathrm{ha}^{-1}$ on sowing, and the remaining side-dressed when the plant has three to eight expanded leaves (Amado et al., 2002). Postponing part of nitrogen fertilization to more advanced growth stages, when plants have greater capacity to take up nutrients, increase nitrogen efficiency use (NEU) (Indicações Técnicas para a Cultura do Milho no RS, 2001).

Because modern commercial hybrids are more productive and require a greater amount of $\mathrm{N}$ to express their yield potential the strategy of postponing part of the $\mathrm{N}$ fertilization to later growth stages is now more feasible (Sangoi et al., 2001). Huber et al. (1994) and Rajcan \& Tollenaar (1999a) showed that modern North American hybrids presented high $\mathrm{N}$ absorption peaks during silking and grain filling. This response shows that there were changes in the $\mathrm{N}$ uptake dynamics and assimilation, in comparison to genotypes released in previous decades.

Nitrogen fertilization at more advanced phenological stages may allow the maintenance of root growth and the integrity of leaf area for a longer period of time, delaying the absorption of nitrogen and other nutrients required for high yield (Hageman \& Below, 1984; Earl $\&$ Tollenaar, 1997). This may be important under circumstances that impair nitrogen side-dressing at the recommended time, such as rainy springs. The objective of this study was to assess the effect of nitrogen side-dressing at the booting and silking stages on agronomic traits of maize hybrids commercially released at different eras.

\section{MATERIAL AND METHODS}

Two experiments were carried out in Eldorado do Sul, RS, southern Brazil $\left(30^{\circ} 01^{\prime} \mathrm{S}, 51^{\circ} 40^{\prime} \mathrm{W}\right.$ and $46 \mathrm{~m}$ of altitude). The climate of the region is wet subtropical with hot summers (Bergamaschi et al., 2003). The soil in the experimental area is classified as Rhodic Kandiudults. The soil attributes during the experimental period were: clay content - $290 \mathrm{~g} \mathrm{~kg}^{-1}$; water $\mathrm{pH}-5.1$; P - $14 \mathrm{mg} \mathrm{kg}^{-1}$; K $125 \mathrm{mg} \mathrm{kg}^{-1}$; organic matter - $23 \mathrm{~g} \mathrm{~kg}^{-1}$; and cationic exchange capacity: $1.1 \mathrm{cmol}_{\mathrm{c}} \mathrm{L}^{-1}$ (Tedesco et al., 1995). Phosphorus and potassium soil contents were assessed through the Mehlich I and Mehlich II methods, respectively. Total nitrogen contents in the soil at planting were 3,204 $\mathrm{kg} \mathrm{ha}^{-1}$ at the 0-20 $\mathrm{cm}$ depth layer (Bayer et al., 2000).
In the 2001/2002 growing season, treatments consisted of two maize cultivars: Pioneer 32R21 (P 32R21), a single-cross, very early hybrid, released in the mid 90's; and Agroceres 303 (AG 303), a double-cross early hybrid, released in the mid 80 's. For each genotype, three rates of $\mathrm{N}$ were side-dressed during the vegetative period $\left(30,80\right.$ and $\left.130 \mathrm{~kg} \mathrm{ha}^{-1}\right)$ and three rates $(0,50$ and $100 \mathrm{~kg}$ $\left.\mathrm{ha}^{-1}\right)$ at silking. Trials were set up in a complete randomized block design, $2 \times 3 \times 3$ factorial scheme $(n=4)$.

In the 2002/2003 growing season, in addition to the two genotypes tested early, two additional maize hybrids were tested: Dekalb 215 (DKB 215) and Syngenta Penta (PENTA), both single-cross early hybrids, released along the last five growing seasons. Each cultivar was submitted to four $\mathrm{N}$ rates, side-dressed at booting $(0,50$, 100 and $150 \mathrm{~kg} \mathrm{ha}^{-1}$ ), in a randomized split-plot design $(n=4)$. Hybrids were located in the main plots and the $\mathrm{N}$ rates at booting in the subplots.

Hybrid AG 303 was first sown at 60,000 plants per ha, on September 20, 2001, and hybrid P32R21 at 75,000 plants per ha, on October 10, 2001. Differences between sowing periods targeted matching the silking stage of both hybrids. Rates of $100 \mathrm{~kg} \mathrm{ha}^{-1}$ of $\mathrm{P}_{2} \mathrm{O}_{5}$ and $\mathrm{K}_{2} \mathrm{O}$ were applied at the AG 303 sowing date. When 50\% of maize seedlings of each hybrid have emerged, $30 \mathrm{~kg}$ $\mathrm{ha}^{-1}$ of $\mathrm{N}$ were applied. The mean and high rates of $\mathrm{N}$ in the vegetative period ( 80 and $130 \mathrm{~kg} \mathrm{ha}^{-1}$ ) were divided in three equal doses, applied at the stages of three to four, seven to eight and ten to 11 expanded leaves. The rates of 50 and $100 \mathrm{~kg} \mathrm{ha}^{-1} \mathrm{~N}$ at silking were applied in a single operation, when $75 \%$ of the plants had visible silks $(0.5$ to $1.0 \mathrm{~cm}$ long) on the ear.

In the second growing season, hybrid AG 303 was sown on October 01, 2002, at 50,000 plants per ha; other hybrids were sown at 70,000 plants per ha. Phosphorus, potassium and nitrogen were banded in the rows during sowing, at rates of $25 \mathrm{~kg} \mathrm{ha}^{-1} \mathrm{~N}, 100 \mathrm{~kg} \mathrm{ha}^{-1} \mathrm{P}_{2} \mathrm{O}_{5}$, and $100 \mathrm{~kg} \mathrm{ha}^{-1} \mathrm{~K}_{2} \mathrm{O}$. Two $\mathrm{N}$ side-dressing were performed in all plots during the vegetative stage: $40 \mathrm{~kg}$ $\mathrm{ha}^{-1}$ when plants had five to six leaves, and $30 \mathrm{~kg} \mathrm{ha}^{-1}$ when plants presented ten to 11 expanded leaves. Rates of $\mathrm{N}$ at booting were applied in a single dose, on the same day for all the hybrids, when $75 \%$ of the earliest hybrid plants (P 32R21) had 15 expanded leaves, corresponding to a period of five to 15 days before silking for the earliest (P 23R21) and the latest (AG 303) hybrid, respectively.

Both trials were hand-sown, in a no-till sowing system, $0.7 \mathrm{~m}$ row spacing. Urea was used as the $\mathrm{N}$ source. Weeds, pests and diseases were controlled throughout the cropping cycle so that they did not interfere in grain yield. A spray system, with $10 \mathrm{~mm} \mathrm{~h}^{-1}$ flow, was used to irrigate the trials whenever the water potential in the soil was lower than $-0,04 \mathrm{MPa}$. 
Each subplot comprised five, 6-m long rows, a total area of $21 \mathrm{~m}^{2}$. Grain yield, yield components and kernel crude protein contents were determined. Grain yield was assessed in the three central rows, excluding $0.5 \mathrm{~m}$ at each row end, comprising an experimental area of $8.4 \mathrm{~m}^{2}$. It was corrected to standard moisture of $13 \%$, and extrapolated to one hectare. Individual kernel weight was determined by counting and weighing 400 grains per experimental unit. Each value was divided by 400 and corrected to the moisture of $13 \%$. The number of grains per $\mathrm{m}^{2}$ was obtained through the ratio between the grain mass produced per $\mathrm{m}^{2}$ and the mass of one grain. A grain sample of $20 \mathrm{~g}$ was ground in a centrifuge-type grinder to determine crude protein contents. The $\mathrm{N}$ contents of grains were obtained by the Kjedahl method, (Tedesco et al, 1995) and multiplied by $6.5(1 \% \mathrm{~N}$ corresponds to 6.25 $\mathrm{g}$ protein), to calculate grain protein contents.

An analysis of variance was performed separately for each growing season ( $F$ teste; $\alpha=0.05$ ). Comparison among means was carried out using the Tukey's test $(\alpha$ $=0.05$ ) during the first growing season. In the second experiment, data from significant effects were submitted to regression analysis, testing linear and quadratic models.

\section{RESULTS AND DISCUSSION}

In $2001 / 2002$, grain yield was affected by interactions between $\mathrm{N}$ levels in the vegetative period $\times \mathrm{N}$ rates at silking and hybrids $\times \mathrm{N}$ rates at silking (Tables 1 and 2). Grain yield response of the two hybrids to nitrogen side-dressing at silking depended on the rate of $\mathrm{N}$ supplied during the vegetative period (Table 1). At the lowest $\mathrm{N}$ rate, grain yield increased 2.8 and $3.6 \mathrm{t} \mathrm{ha}^{-1}$, with the application of 50 and $100 \mathrm{~kg} \mathrm{ha}^{-1} \mathrm{~N}$ at silking, respectively, compared to the control. At the highest $\mathrm{N}$ level,

Table 1 - Grain yield and number of grains per ear at three nitrogen levels $(\mathrm{N})$ side-dressed in the vegetative period and two $\mathrm{N}$ rates applied at silking, in the average of two maize hybrids ${ }^{1}$.

\begin{tabular}{|c|c|c|c|}
\hline \multirow{2}{*}{$\begin{array}{l}\text { Nitrogen levels applied } \\
\text { in the vegetative period }\end{array}$} & \multicolumn{3}{|c|}{ Rates of nitrogen applied at silking } \\
\hline & 0 & 50 & 100 \\
\hline \multicolumn{4}{|c|}{ - } \\
\hline & \multicolumn{3}{|c|}{ Grain yield $\left(\mathrm{t} \mathrm{ha}^{-1}\right)$} \\
\hline 30 & B $4.4 \mathrm{c}$ & A $7.2 \mathrm{c}$ & A $8.0 \mathrm{c}$ \\
\hline 80 & A $10.4 \mathrm{~b}$ & A $11.1 \mathrm{~b}$ & A $11.3 \mathrm{~b}$ \\
\hline \multirow[t]{2}{*}{130} & B $11.4 \mathrm{a}$ & $\mathrm{AB} 12.1 \mathrm{a}$ & A 13.1 a \\
\hline & \multicolumn{3}{|c|}{ Grains per ear $\left(n^{\circ}\right)$} \\
\hline 30 & B $282 \mathrm{~b}$ & A $363 \mathrm{~b}$ & A $369 \mathrm{~b}$ \\
\hline 80 & A 540 a & A 528 a & A 524 a \\
\hline 130 & A 556 a & $\mathrm{AB} 528 \mathrm{a}$ & A 548 a \\
\hline
\end{tabular}

${ }^{1}$ Means followed by the same lower case letter in the column and preceded by the same upper case letter on the line - not differ (Tukey's test, $\alpha=0.05$ ). increases were 0.7 and $1.7 \mathrm{t} \mathrm{ha}^{-1}$, respectively, with the application of 50 and $100 \mathrm{~kg} \mathrm{ha}^{-1} \mathrm{~N}$ at silking. There were no responses to $\mathrm{N}$ application at silking for the intermediary $\mathrm{N}$ rate in the vegetative period.

Grain yield of the two hybrids differed in relation to $\mathrm{N}$ application at silking, (Table 2). The doublecross hybrid AG 303 responded up to the application of $50 \mathrm{~kg} \mathrm{ha}^{-1} \mathrm{~N}$, increasing $1.5 \mathrm{t} \mathrm{ha}^{-1}$ in yield. The singlecross hybrid P 32R 21 responded up to the application of $100 \mathrm{~kg} \mathrm{ha}^{-1} \mathrm{~N}$ at silking, with increases in yield of 2.7 $\mathrm{t} \mathrm{ha}^{-1}$, in comparison to the treatment without $\mathrm{N}$ application at this stage.

In the experiment carried out in 2002/2003, interactions between hybrids and $\mathrm{N}$ rates applied at booting affected grain yield. The response of grain yield to $\mathrm{N}$ application at booting was linear for PENTA and quadratic for the other hybrids (Figure 1). For each $\mathrm{kg}$ of $\mathrm{N}$ applied at booting, an increase of $14 \mathrm{~kg}$ in the grain yield of PENTA was recorded. The estimated $\mathrm{N}$ rates at boot-

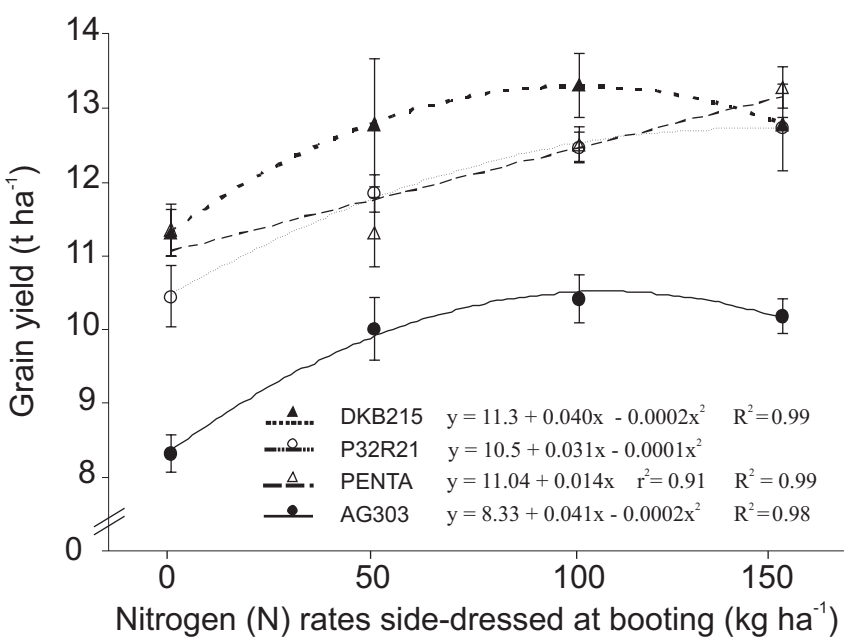

Figure 1 - Grain yield of four maize hybrids as a function of four nitrogen $(\mathrm{N})$ rates side-dressed at booting. Error bars represent the standard error of mean (Tukey's test; $\alpha=0.05$ ).

Table 2 - Grain yield and kernel crude protein content of two maize hybrids and three rates of nitrogen $(\mathrm{N})$ applied at silking, in the average of three $\mathrm{N}$ rates side-dressed during the vegetative period ${ }^{1}$.

\begin{tabular}{lccc}
\hline \multirow{2}{*}{ Hybrids } & \multicolumn{4}{c}{ Rates of nitrogen applied at silking } \\
\cline { 2 - 4 } & \multicolumn{4}{c}{50} & 100 \\
\hline & B $7.9 \mathrm{~b}$ & A $9.4 \mathrm{~b}$ & A $9.2 \mathrm{~b}$ \\
Agroceres 303 & C 9.7 a & B $10.8 \mathrm{a}$ & A 12.4 a \\
\hline Pioneer 32R21 & Kernel crude protein content $(\%)$ \\
Agroceres 303 & B 6.9 a & B 8.2 a & A 10.5 a \\
Pioneer 32R21 & AB 7.3 a & B 7.1 a & A 8.5 b \\
\hline
\end{tabular}

${ }^{1}$ Means followed by the same lower case letter in the column and preceded by the same uppercase letter on the line - not differ (Tukey's test, $\alpha=0.05$ ). 
ing that optimized grain yield were 103,150 and $100 \mathrm{~kg}$ $\mathrm{ha}^{-1}$ for AG 303, P 23R21 and DKB 215, respectively. Confirming the results of the first experiment, the doublecross hybrid AG 303 presented lower grain yields than the more recent single-cross hybrids, regardless of nitrogen rates applied at booting.

Enhancements in grain yield with late nitrogen side-dressing in 2001/2002 can be attributed to increasing number of grains per ear, when $50 \mathrm{~kg} \mathrm{ha}^{-1}$ of $\mathrm{N}$ were applied at silking during the vegetative period (Table 1). Conversely, the increase in grain weight was responsible for higher yields when the rate of $\mathrm{N}$ applied at silking increased from 0 to $100 \mathrm{~kg} \mathrm{ha}^{-1}$, regardless of the amount of $\mathrm{N}$ applied in the vegetative period or the kind of hybrid tested in the trial (Table 3). The number of ears produced per area was not affected by $\mathrm{N}$ application at silking or booting (data not presented). This may have occurred because this yield component had already been defined previously to the timing of $\mathrm{N}$ application. Another factor that may have prevented the response of this component was that the rate of $\mathrm{N}$ available in the vegetative period was relatively high $\left(95 \mathrm{~kg} \mathrm{ha}^{-1}\right)$ in the experiment with $\mathrm{N}$ application at booting.

Table 3 - Grain weight at three nitrogen rates (N) applied at silking, in the average of two maize hybrids and three $\mathrm{N}$ rates side-dressed in the vegetative period ${ }^{1}$.

\begin{tabular}{lc}
\hline Rates of nitrogen applied at silking & Grain weight \\
\hline $\mathrm{kg} \mathrm{ha}^{-1}$ & $\mathrm{mg}$ \\
0 & $280 \mathrm{c}$ \\
50 & $300 \mathrm{~b}$ \\
100 & $320 \mathrm{a}$ \\
\hline
\end{tabular}

${ }^{1}$ Means followed by the same lower case letter in the column did not differ (Tukey's test; $\alpha=0.05$ ).

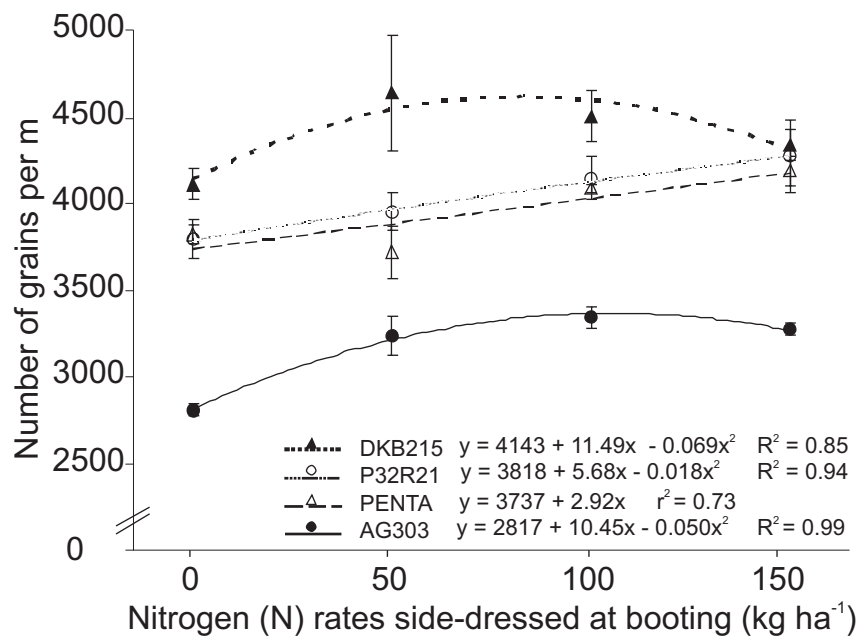

Figure 2 - Number of grains of four maize hybrids as a function of four nitrogen $(\mathrm{N})$ rates side-dressed at booting. Error bars represent the standard error of mean values (Tukey's test; $\alpha=0.05$ ).
The number of grains $\mathrm{m}^{-2}$ (Figure 2) and grain weight (Figure 3) of PENTA increased linearly with increasing rates of $\mathrm{N}$ fertilization at booting. These increases were 2.92 grains $\mathrm{m}^{-2}$ and $0.13 \mathrm{~g}$, for each $\mathrm{kg}$ of applied $\mathrm{N}$, respectively. The response of these yield components in the other hybrids was quadratic. The $\mathrm{N}$ rates side-dressed at booting that optimized the number of grains $\mathrm{m}^{-2}$ were 104 , 125 and $83 \mathrm{~kg} \mathrm{ha}^{-1}$ for the hybrids AG 303, P 32R21 and DKB 215, respectively. Rates of nitrogen fertilization that resulted in heavier grains were 111,125 and $48 \mathrm{~kg} \mathrm{ha}^{-1}$ for the hybrids AG 303, P 32R21 and DKB 215, respectively.

The greater grain yield of more recent hybrids P32R21 and Penta, in comparison to hybrids released in the mid 80's, AG 303 for instance, can be associated to the higher number of grains per area (Figure 2) in 2002/ 2003 , and to the combined effect of grain weight and number of grains per ear (Tables 1 and 3) in 2001/2002. In both trials, the weight of 1,000 grains was the yield component that showed the most consistent response to $\mathrm{N}$ fertilization at booting and silking.

Nitrogen application at silking also increased kernel crude protein content (Table 2), up to the application of $100 \mathrm{~kg} \mathrm{ha}^{-1} \mathrm{~N}$, grain protein percentage being 52 and $16 \%$ higher than the control for AG 303 and P 32R21, respectively. This response showed that $\mathrm{N}$ applied during flowering was taken by the plant and accumulated in the grains. Nitrogen side-dressing at booting affected grain protein contents of tested hybrids in a different way (Figure 4). The response was linear for AG 303, P 32R 21 and DKB 215, with increases of nine, 15 and $41 \%$ in protein content for each $100 \mathrm{~kg} \mathrm{~N}$ applied at booting. The optimal rate of $\mathrm{N}$ at booting to maximize the PENTA crude protein content was $100 \mathrm{~kg} \mathrm{ha}^{-1}$.

There was an inverse relationship in the quantitative and qualitative responses of maize kernels to nitrogen side-dress at booting. PENTA presented linear in-

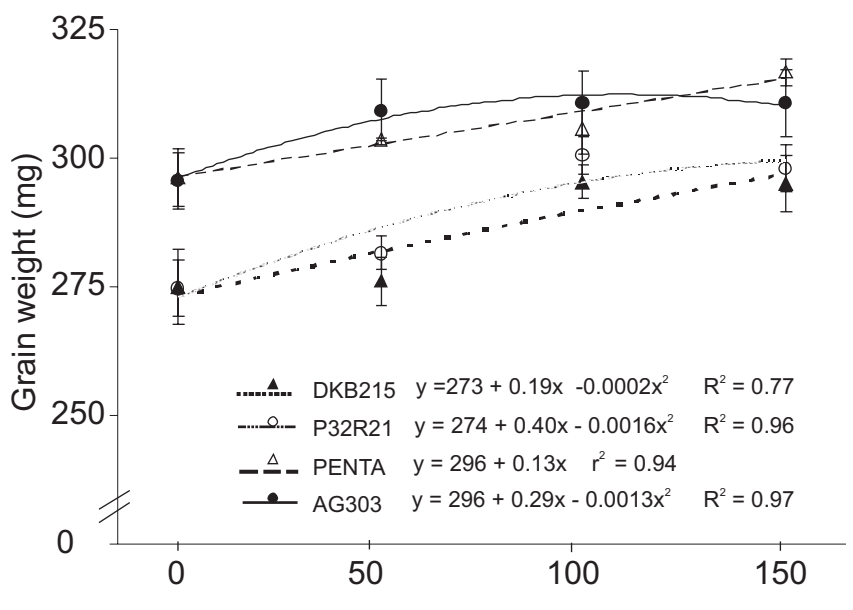

Nitrogen $(\mathrm{N})$ rates side-dressed at booting $\left(\mathrm{kg} \mathrm{ha}^{-1}\right)$

Figure 3 - Grain weight of four maize hybrids as a function of four nitrogen $(\mathrm{N})$ rates side-dressed at booting. Error bars represent the standard error of mean values (Tukey's test; $\alpha=0.05$ ). 


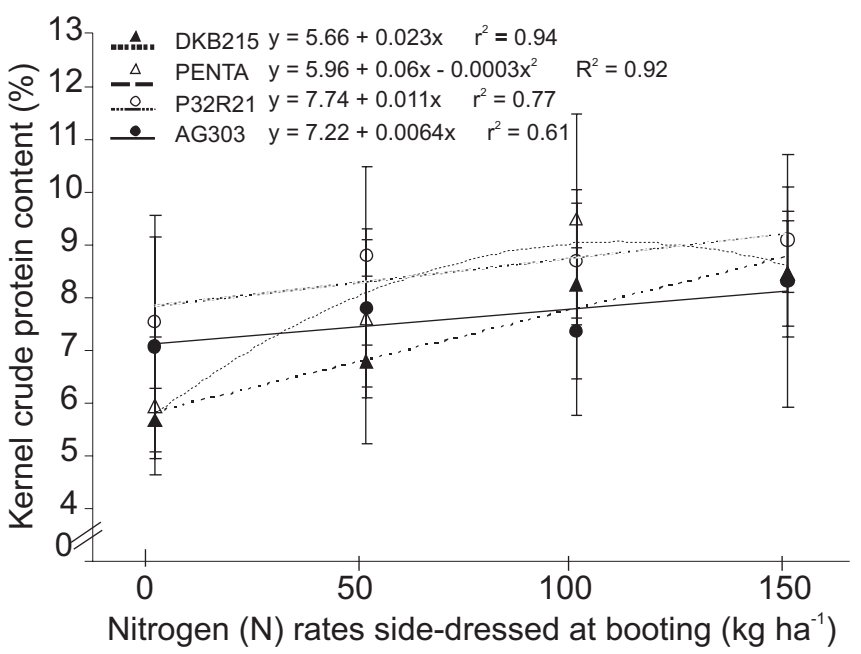

Figure 4 - Kernel crude protein content of four maize hybrids as a function of four nitrogen $(\mathrm{N})$ rates side-dressed at booting. Eldorado do Sul, RS, Brazil, 2002/2003. The error bars represent the standard error of mean values (Tukey's test; $\alpha=0.05$ ).

crease in grain yield and quadratic response for grain protein content, while the other hybrids showed quadratic increases in grain yield and linear responses in grain protein contents (Figures 1 and 4). Although no increases in grain yield with high $\mathrm{N}$ rates were recorded, kernels of AG 303, P 32R21 and DKB 215 continued demanding $\mathrm{N}$ and storing the nutrient as protein.

$\mathrm{N}$ side-dressing at silking mitigates loss of grain yield potential, mainly when $\mathrm{N}$ supply during the vegetative stages is insufficient, and nitrogen deficiency more accentuated at flowering. According to Binder et al. (2000), when nitrogen deficiency is greater at the beginning of maize development, $\mathrm{N}$ should be side-dressed earlier to obtain maximum grain yield. However, the determination of an ideal period for $\mathrm{N}$ application differs from the definition of a phenological stage where it is still possible to get a yield positive response to fertilizer application. Grain yield and kernel crude protein contents increases can be obtained with late $\mathrm{N}$ application whenever there is deficiency of this nutrient during the vegetative period, although the crop yield potential has already been hindered and can no longer be reached. An economically viable response can be observed with the application of mineral nitrogen up to silking under undesirable climatic conditions that either delay $\mathrm{N}$ application, or favor high $\mathrm{N}$ losses during maize vegetative period (Scharf et al., 2002). This was the case in the first experiment. Application of $50 \mathrm{~kg} \mathrm{ha}^{-1} \mathrm{~N}$ at silking promoted $63.6 \%$ increment in grain yield over the control, receiving only 30 $\mathrm{kg} \mathrm{ha}^{-1}$ during the crop vegetative period.

The differential response to late $\mathrm{N}$ side-dressing among cultivars developed in different periods may have occurred because many current hybrids keep the integrity of leaf area for a longer period, which contributes to the greater synthesis of photoassimilates during grain fill- ing. The stay-green trait has been emphasized by many breeding programs because delay in leaf senescence is associated with higher grain yield (Wolfe et al., 1988; Dwyer \& Tollenaar, 1989; Dwyer et al., 1991; McCullough et al. 1994). The prolonged maintenance of leaf area for photoassimilate production during grain filling and the ability to up take $\mathrm{N}$ from the soil after flowering characterize maize hybrids with highly efficient use of N (Dwyer et al. 1995). The capacity of maize to maintain $\mathrm{N}$ uptake during the filling period may be related to the supply of carbohydrates to the root (Rajcan \& Tollenaar, 1999a). Therefore, considering that older hybrids, such as AG 303, established a weak drain during the beginning of kernel formation due to their lower yield potential, it is more likely that poor sinking lead to a reduction in $\mathrm{N}$ demand inside the plant, decreasing $\mathrm{N}$ uptake by roots after silking, and its remobilization from the leaves and stem to the grains (Sangoi et al., 2001). It can thus be speculate that many modern hybrids, such as P23R21 and PENTA, have greater capacity to uptake $\mathrm{N}$ from the soil and to mobilize it from the vegetative tissues to the grains after silking, resulting in delayed leaf senescence, prolonged filling period and heavier grain production. This physiological sequence of events elicits a more balanced source:demand ratio, resulting in higher N efficiency use (Rajcan \& Tollenaar, 1999a; 1999b).

Grain protein quality was not assessed in the study. However, protein quality (type and quantity of amino acids present) is a relevant factor for producers and consumers, especially when grain quality determines the final price of the commodity. Tsai et al. (1992) showed that increases in protein content in maize grains driven by nitrogen side-dressing were derived from greater quantity of zein. This protein is deficient in lysine and triptophane, two essential amino acids for species such as pigs and poultry. Consequently, it is possible that protein quality is not improved with late $\mathrm{N}$ side-dressing. Another possible advantage of increasing grain protein content with late $\mathrm{N}$ side-dressing is reducing kernel susceptibility to breakage at harvesting, a feature that allows greater aggregation of commercial value to the product (Tsai et al., 1992).

Several modern hybrids can up take up and assimilate $\mathrm{N}$ efficiently during silking, contradicting the premise that the impact of nitrogen side-dressing after flowering on grain yield is negligible. The use of late nitrogen side-dressing is advantageous particularly when adequate quantities of $\mathrm{N}$ are not supplied during the vegetative period. This situation commonly occurs under water stress, caused either by deficient or excessive rainfall during the crop cycle. Another potential advantage of spreading nitrogen side-dresses in a longer period of time is the reduction of $\mathrm{N}$ losses from volatilization and leaching, lowering negative impact on environmental resources and human health. This is particularly important 
Table 4 - Comparison of maize yield at identical total $\mathrm{N}$ rates and different times of nitrogen aplication, in the average of two maize hybrids.

\begin{tabular}{lccc}
\hline Total N rate vegetative + silking & \multicolumn{2}{c}{ Grain yield } \\
\hline $\mathrm{kg} \mathrm{ha}^{-1}$ & $10.4(80+0)^{1}$ & $7.2(30+50)$ & - \\
80 & $11.4(130+0)$ & $11.1(80+50)$ & $8.0(30+100)$ \\
130 & $12.1(130+50)$ & $11.3(80+100)$ & - \\
\hline
\end{tabular}

${ }^{1}$ The two values in parenthesis represent the $\mathrm{N}$ rate at vegetative stage and silking, respectively.

when high $\mathrm{N}$ rates are used during the entire crop cycle, a common situation in production systems designed to reach yield rates close to the crop's fall potential.

On the other hand, $\mathrm{N}$ use efficiency is usually higher when applications are carried out when maize has three to eight expanded leaves (Amado et al., 2002). At each total $\mathrm{N}$ rate, yield was always higher when all or most $\mathrm{N}$ was applied before silking than when part of total $\mathrm{N}$ was applied at silking (Table 4). This illustrates the importance of $\mathrm{N}$ fertilization during vegetative stage. As a result, $\mathrm{N}$ applications at booting or silking should not be recommended as part of routine $\mathrm{N}$ application scheme, but rather as a remedy in case of undesirable crop nutrition when entering reproductive phase. In addition to that, the availability of suitable machinery to apply $\mathrm{N}$ at late growth stages is a limiting factor to the adoption of this management strategy. Nonetheless, the offer of highclearance applicators is increasing (Scharf et al., 2002). Furthermore, the demand for more modern agricultural equipment has been met by the industry whenever the effectiveness of a new technique is worthwhile. An example of this situation occurred with the development of sowing machinery designed specifically for the no-till sowing system. Ferti-irrigation is another alternative to carry out late $\mathrm{N}$ side-dressing in areas where irrigation is available. On small farms, this crop management practice can be performed manually by producers.

\section{ACKNOWLEDGMENT}

To CNPq for the scholarship and research grants.

\section{REFERENCES}

AMADO, T.J.C.; MIELNiCZUK, J.; VEZZANI, F.M. Nova recomendação de adubação nitrogenada para o milho sob plantio direto no RS e SC adaptada ao uso de cobertura do solo. Revista Plantio Direto, v.3, p.30-35, 2002.

BAYER, C.; MIELNICZUK, J.; AMADO, T.J.C.; MARTIN-NETO, L.; FERNANDES, S.V. Organic matter storage in a sandy clay loam Acrisol affected by tillage and cropping systems in southern Brazil. Soil \& Tillage Research, v.54, p.101-109, 2000.

BERGAMASCHI, H.; GUADAGNIN, M.R.; CARDOSO, L.S.; SILVA, M.I.G. Clima da Estação Experimental da UFRGS (e região de abrangência). 2.ed. Porto Alegre: UFRGS, 2003. 77p.

BINDER, D.L.; SANDER, D.H.; WALTERS, D.T. Maize response to time of nitrogen application as affected by level of nitrogen deficiency. Agronomy Journal, v.92, p.1228-1236, 2000.
DWYER, L.M.; ANDERSON, A.M.; STEWART, D.W.; MA, B.L.; TOLLENAAR, M. Changes in maize hybrid photosynthetic response to leaf nitrogen, from pre-anthesis to grain filling. Agronomy Journal, v.87, p.1221-1225, 1995.

DWYER, L.M.; TOLLENAAR, M. Genetic improvement in photosynthetic response of hybrid maize cultivars 1959 to 1988. Canadian Journal of Plant Science, v.69, p.81-89, 1989.

DWYER, L.M.; TOLLENAAR, M.; STEWART, D.W. Changes in plant density dependence of leaf photosynthesis of maize (Zea mays L.) hybrids, 1959 to 1988. Canadian Journal of Plant Science, v.71, p.111, 1991.

EARL, H.J.; TOLLENAAR, M. Maize leaf absorptance of photosynthetically active radiation and its estimation using chlorophyll meter. Crop Science, v.37, p.436-440, 1997.

HAGEMAN, R.H.; BELOW, F.E. The role of nitrogen in the productivity of corn. In: ANNUAL CORN \& SORGHUM RESEARCH CONFERENCE, 39., Chicago, 1984. Proceedings. Chicago: American Seed Trade Association, 1984. p.145-155.

HUBER, D.M.; TSAI, C.Y.; STROMBERGER, J.A. Interaction of K with $\mathrm{N}$ and their influence on growth and yield potential of maize. In: ANNUAL CORN AND SORGHUM RESEARCH CONFERENCE, 48., Chicago, 1994. Proceedings. Chicago: American Seed Trade Association, 1994. p.165-176.

INDICAÇÕES técnicas para a cultura do milho no RS..Porto Alegre: FEPAGRO; EMATER/RS; FECOAGRO/RS, 2001. 196p. (Boletim 7).

MCCULLOUGH, D.E.; AGUILERA, A.; TOLLENAAR, M. N uptake, N partitioning, and photosynthetic N-use efficiency of an old and a new maize hybrid. Canadian Journal of Plant Science, v.74, p.479-484, 1994.

RAJCAN, I.; TOLLENAAR, M. Source: sink ratio leaf senescence in maize. I. Dry matter and partitioning during grain filling. Field Crops Research, v.60, p.245-254, 1999a.

RAJCAN, I.; TOLLENAAR, M. Source: sink ratio leaf senescence in maize. II. Nitrogen metabolism during grain filling. Field Crops Research, v.60, p.255-265, 1999b.

RAUN, W.R.; JOHNSON, G.V. Improving nitrogen use efficiency for cereal production. Agronomy Journal, v.91, p.357-363, 1999.

SANGOI, L.; ENDER, M.; GUIDOLIN, F.A.; KONFLANZ, V.A. Nitrogen fertilization impact on agronomic traits of maize hybrids released at different decades. Pesquisa Agropecuária Brasileira, v.36, p.757-764, 2001.

SCHARF, P.C.; WIEBOLD, W.J.; LORY, J.A. Corn yield response to nitrogen fertilizer timing e deficiency level. Agronomy Journal, v.94, p.435-441, 2002.

TEDESCO, M.J.; GIANELLO, C.; BISSANI, C.A.; VOLKWEISS, S.J. \& BOHNEN, H. Análises de solo, plantas e outros materiais. 2.ed. Porto Alegre: UFRGS, Departamento de Solos, 1995. 174p. (Boletim Técnico, 5)

TSAI, C.Y.; DWEIKAT, I.; HUBER, D.M.; WARREN, H.L. Interelationship of nitrogen nutrition with maize (Zea mays L.) grain yield, nitrogen efficiency and grain quality. Journal of Science and Food Agriculture, v.58, p.1-8, 1992

WOLFE, D.W.; HENDERSON, D.W.; HSIAO, T.C.; ALVINO, A. Interactive water and nitrogen effects on senescence of the maize. I. Leaf area duration, nitrogen distribution and yield. Agronomy Journal, v.80, p.859-864, 1988.

Received January 17, 2005

Accepted August 03, 2005 